\title{
Insurance as a factor affecting the effectiveness of the financial mechanism of the governing structures
}

\author{
Natalia Vaynshtok ${ }^{1, *}$ \\ ${ }^{1}$ Moscow State University of Civil Engineering, Yaroslavskoye shosse, 26, Moscow, 129337, Russia
}

\begin{abstract}
The article analyzes the activities of the managing development structures of the construction industry. The conditions for the development of modern market relations require the mobilization of all external and internal resources of the management structures. For this purpose, a system of financial mechanism has been developed, the most important element in the financial relations of which is insurance. The study presents insurance objects, defines types of insurance contracts, identifies guarantees for ensuring financial sustainability. The experts are offered a formula for the actual margin of solvency of the insurer, measures are developed to improve and improve the effectiveness of financial mechanisms of managing structures.
\end{abstract}

\section{Introduction}

The current state of the construction industry is characterized by an increase in investment activity, especially in the budgetary sphere. Under construction on a hard competitive basis are given hectares of land. The mechanisms of co-investment between managers and managed companies are updated. The market dictates new standards of financial mechanisms of all participants of the construction business and improvement of their financial relations. In order to improve the efficiency of the building complex and its management structures.

The financial mechanism of an enterprise is a system for managing financial relations through financial leverage through financial methods.

Financial relations at the enterprise level cover:

- relations with insurance companies and organizations for insurance of commercial and financial risks;

- Relations with other enterprises and organizations for the supply of raw materials, material-completing products, sales of products, provision of services, etc .;

- relations with the banking system for the calculation of banking services, with the receipt and repayment of loans; buying and selling currencies and other transactions;

- Relations with commodity, commodity and stock exchanges on operations with industrial and financial assets;

* Corresponding author: nvainshtok@mail.ru 
- relations with investment institutions (funds, companies) in the allocation of investments, privatization, etc.;

- relations with branches and subsidiaries;

- relations with the personnel of the enterprise for payment of wages, dividends, etc .;

- Relations with shareholders (not members of the work collective);

- relations with the tax service for the payment of taxes and other payments;

- Relations with audit firms and other business entities.

Common to all types of relations listed is that they are expressed in monetary form and represent a set of payments and receipts of cash assets of the enterprise.

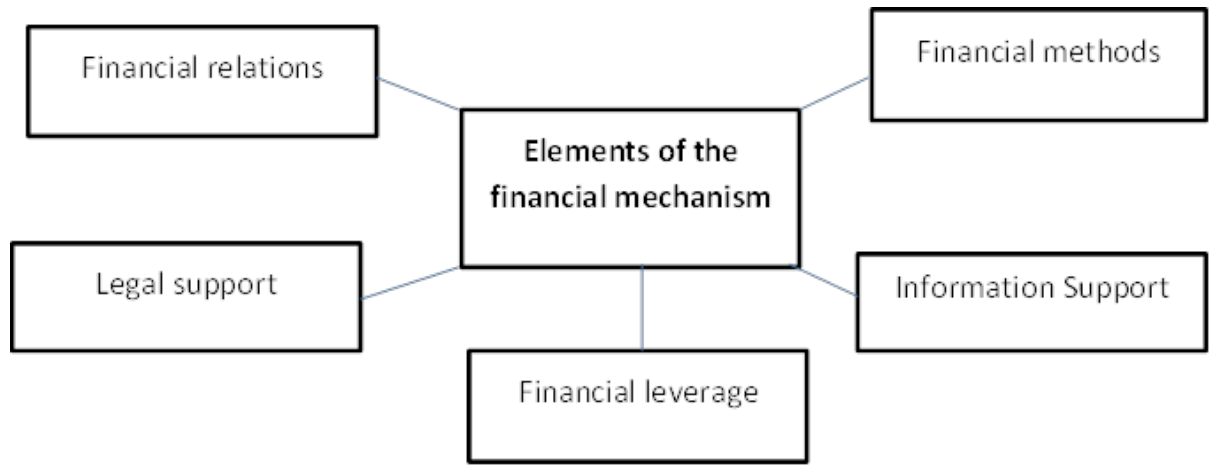

Fig. 1. Elements of the financial mechanism.

Financial leverage is a set of financial indicators through which the management system can influence the economic activities of the enterprise. They include: profit, income, financial sanctions, price, dividends, wages, taxes, investments, rents, interest, discounts, ruble exchange rate quotes, etc.

Legal maintenance of the functioning of the financial mechanism includes:

- Legislative acts;

- regulations;

- orders and other legal documents of the management bodies.

Information support for the functioning of the financial mechanism consists of various types and types of economic, commercial, financial and other information.

Financial information includes:

- information on the financial stability and solvency of its partners and competitors, on prices, rates, dividends, interest on commodity, stock and currency markets, etc .;

- a statement on the situation on the stock exchange, over-the-counter markets, the financial and commercial activities of any worthy attention of economic entities;

- other information.

In the course of its activities the enterprise enters into various financial relations with numerous entities, participants in this relationship, including with insurance companies on insurance operations

\section{Materials and methods}

Insurance means economic relations for the creation of special money funds from contributions of individuals and legal entities and the subsequent use of these funds to compensate the same or other persons for damage (harm) upon receipt of various adverse (extraordinary) events. 
Insurance is one of the tools of risk management, protection of property interests of enterprises and citizens against various risks in the event of occurrence of certain events of insurance events at the expense of funds generated from the insurance premiums paid by them. Insurance is provided by insurance companies.

Insurance refers to the service sector. The enterprise (acting as an insurer) pays insurance premiums to the insurer (insurance premiums), that is, it makes insurance payment, and the insurer, in turn, in the event of certain insured events, makes insurance payments directly to the insured or makes insurance payments in favor of third parties (insured) .

Insurance can be carried out in two forms. Obligatory insurance is carried out by virtue of the law (for example, compulsory insurance against accidents of miners, obligatory medical insurance).

Voluntary insurance is carried out on the basis of a contract concluded between the enterprise and an insurance organization. Voluntary form of insurance reflects individual and collective (group) insurance needs.

Insurance is carried out on the basis of insurance contracts (Table 1), concluded by the insured with the insurer.

Stages of interaction between the enterprise and the insurance organization:

- preliminary negotiations, under which the parties agree on the main terms of the insurance contract;

- preparation, signing and payment of the insurance contract (the enterprise transfers the insurance payment to the account of the insurance organization)

- Settlement of the loss (in the event of an insurance event and the implementation of insurance payments).

Insurance is the protection of the interests of individuals and legal entities, the state and municipal entities when certain insured events occur at the expense of monetary funds generated by insurers from insurance premiums paid (insurance premiums), as well as at the expense of other insurer funds.

Insurers are legal entities established for the implementation of insurance (as well as reinsurance, mutual insurance) and have a corresponding license.

Insurance can be voluntary and mandatory. Terms and procedure for the implementation of specific types of compulsory insurance are determined by the relevant laws. Voluntary insurance is carried out on the basis of rules that determine the general conditions and procedure for its implementation and are approved by the insurer and the insurance contract that is concluded between the insurer and the insured. Types of voluntary insurance contracts are presented in Table 1.

Since the financial obligations of insurers depend on events that are beyond their control, the issue of financial stability becomes especially important for insurers.

Table 1. Types of voluntary insurance contracts.

\begin{tabular}{|c|c|c|}
\hline Personal insurance & Property Insurance & Liability Insurance \\
\hline $\begin{array}{l}\text { insurance against accidents } \\
\text { at work (the contract is } \\
\text { concluded for the benefit of } \\
\text { the employees of the } \\
\text { enterprise or members of } \\
\text { their families), etc .; } \\
\text { - voluntary medical } \\
\text { insurance of employees of } \\
\text { the enterprise }\end{array}$ & $\begin{array}{l}\text { - Insurance of the property of } \\
\text { the enterprise (for example, in } \\
\text { case of fire, theft, gas } \\
\text { explosion, etc.); } \\
\text { - cargo insurance; } \\
\text { - insurance of means of land, } \\
\text { air and water transport }\end{array}$ & $\begin{array}{l}\text { - insurance of civil liability of } \\
\text { enterprises - sources of } \\
\text { increased danger (the property } \\
\text { of insurance is the property } \\
\text { interests of persons in whose } \\
\text { favor the insurance contract is } \\
\text { concluded); } \\
\text { - insurance of civil liability of } \\
\text { enterprises - owners of motor } \\
\text { vehicles }\end{array}$ \\
\hline
\end{tabular}

Insurance rate - the rate of the insurance premium (remuneration of the insurer) from the 
unit of the insured amount taking into account the object of insurance and the nature of the insurance risk. Own means of insurance companies include the authorized capital, reserve capital, additional capital, undistributed profit. No extra funds are allowed into the authorized capital of the borrowed funds and property that is in the pledge. Insurance reserves are financial resources that are separated by the insurer specifically to ensure fulfillment of insurance obligations (reinsurance, mutual insurance) in the established order (Figure 2).

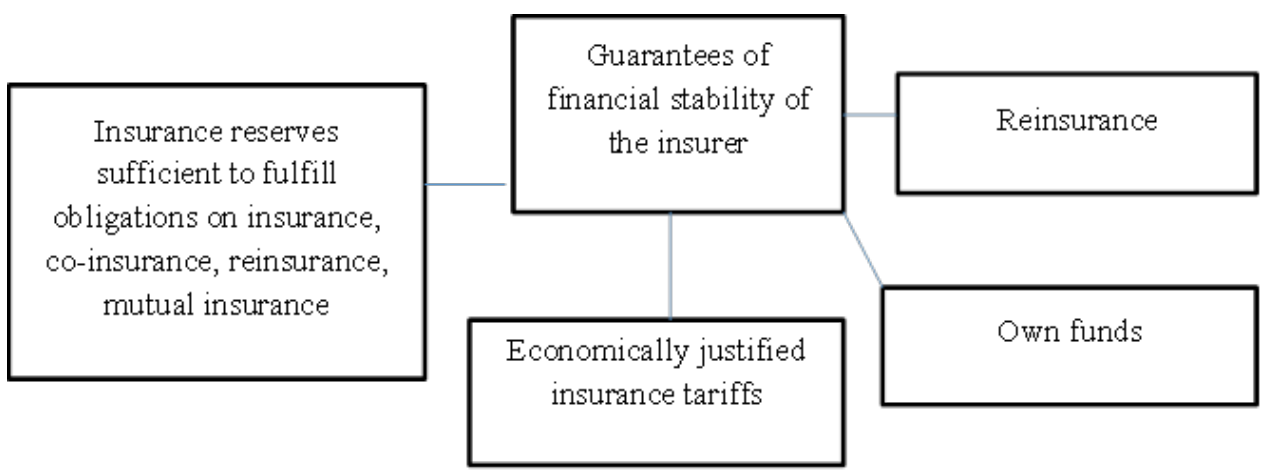

Fig. 2. Guarantees of ensuring the financial stability of the insurer.

The means of insurance reserves are used exclusively for the implementation of insurance payments. Insurers have the right to invest and otherwise dispose of insurance reserves in the prescribed manner. Insurers on the basis of the results of each year are obliged to carry out an actuarial valuation of the accepted insurance obligations and insurance reserves and provide its results to the insurance supervisory authority.

To implement life insurance, the insurer approves special rules for the formation of insurance reserves for life insurance, which are subject to agreement in the insurance supervision body (Figure 3). Thus, under life insurance contracts, the reserve is determined on the basis of a long-term calculation agreed by the supervisory authority. In addition, in the case of long-term life insurance, the insurer is entitled to provide the insured individual with a loan within the amount of the corresponding insurance reserve.

Under insurance contracts other than life insurance, the reserve is recalculated at the end of each reporting period on the basis of an assessment of the accepted insurance risks.

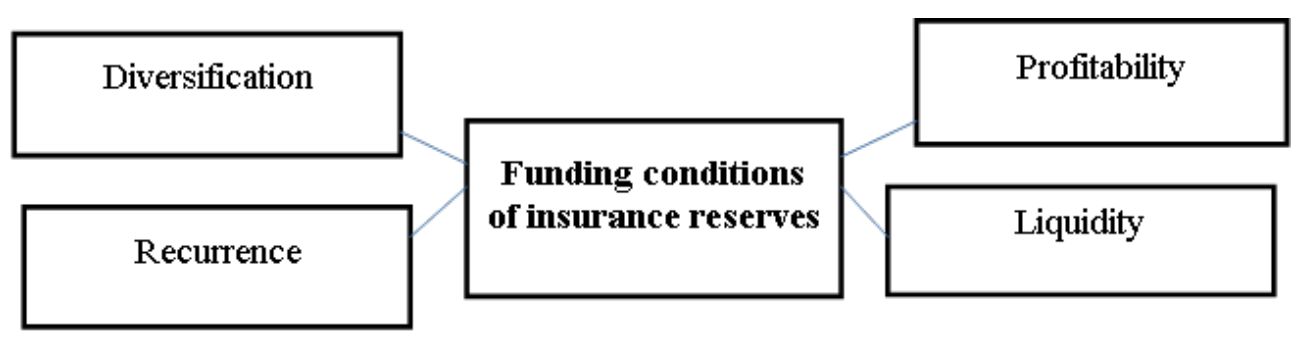

Fig. 3. Conditions for placement of insurance reserves.

Measures to implement this approach are detailed in regulatory enactments that establish requirements for assets, which must be ensured by insurance reserves and own means of the insurer.

\section{Results}


Finance in certain types of economic activity these requirements operate with the concept of "insurer's solvency margin".

The normative margin of the insurer's solvency is the amount by which the insurer, in order to ensure the fulfillment of obligations assumed, must have its own capital reduced by the amount of low-liquid assets.

The normative margin of solvency is calculated as the sum of the normative margin of payment-ability under life insurance contracts and other insurance contracts. In this case, the normative margin of solvency in any case cannot be less than the minimum amount of the authorized capital for this type of insurer.

The actual margin of solvency of the insurer $(\mathrm{Fd})$ is:

$\mathrm{Fd}=\mathrm{Fc}(\mathrm{U} ; \mathrm{R} ; \mathrm{S} ; \mathrm{P})$-Fl (A; T; K; O), where:

$\mathrm{Fc}$ - own means of the insurer:

$\mathrm{U}$ - authorized capital,

$\mathrm{R}$ - reserve capital,

$\mathrm{S}$ - additional capital,

$\mathrm{P}$ - retained earnings, reduced by the amount of uncovered losses

Fl- Low liquid assets:

A - intangible assets,

$\mathrm{T}$ - overdue accounts receivable,

$\mathrm{K}$ - accounts receivable for payment of the authorized capital,

$\mathrm{O}$ - own shares redeemed from shareholders.

The regulatory requirements for the ratio of the assets of the insurer and the insurance obligations accepted by him are as follows:

- the insurer quarterly compares the amount of the actual and normative margin of payment-ability;

- the actual amount of solvency margin should not be less than the normative;

- if the actual solvency margin exceeds the regulatory solvency by less than $30 \%$, the insurer shall develop a recovery plan for the financial situation and submit it to the insurance supervisory authority as part of the annual financial statements.

The regulatory requirements for the structure and composition of assets taken to cover the insurer's own funds are as follows: the insurer's own funds must be covered by returnable, profitable, liquid and diversified assets in the amount of not less than the normative difference between the assets and obligations of the insurer calculated as normative Margin solvency, increased by a factor (1,1-1,3) depending on the type of insurance. The document contains a list of assets that are not taken to cover the insurers 'own funds, a list of assets taken to cover the insurers' own funds, specifying the requirements for the permitted assets and the maximum share of each of them in the insurer's portfolio.

The requirements for the composition and structure of the assets taken to cover insurance reserves are set by the Order of the Ministry of Finance of Russia No. 10n of July 2, 2012, determine that the insurance reserves generated by the insurer must be covered by diversified, refundable, profitable and liquid assets.

\section{Discussions}

The plan specifies specific activities that contribute to the stabilization of the financial situation, indicating the duration of the event and the amount of revenue (savings) that is planned to be received from the activity.

To the plan of improving the financial situation and increasing the efficiency of financial mechanisms of companies, the calculation is made of the ratio between the actual and normative amounts of the solvency margin planned for the end of each financial year 
(during the implementation of the plan). In terms of improving the financial situation and improving the efficiency of the financial mechanism of the management structure, it can be stipulated:

-change of the authorized capital;

-extension of reinsurance operations;

-change of tariff policy;

- reduction of accounts receivable and accounts payable;

- change in the structure of assets;

- the use of other methods of maintaining solvency, not inconsistent with the law.

\section{Conclusion}

The proposals on improving financial relations in the modern construction complex allow us not only to reduce construction risks, increase the profitability of managing structures, but also to improve the quality of construction products and the quality of life of the Russian population. Insurance of the responsibility of all construction participants is the most important factor in improving the efficiency of the construction industry, guaranteeing the safety of citizens.

\section{References}

1. A. Larionov, Journal of legal and economic studies 3, 234-238 (2014)

2. A. Borboni, M. Mor, R. Faglia, Journal of Dynamic Systems, Measurement and Control, Transactions of the ASME 138 (11), 111003 (2016)

3. A. Larionov, E. Nezhnikova, International Journal of Applied Engineering Research 6 (11), 4433-4439 (2016)

4. A. Larionov, E. Nezhnikova, ARPN Journal of Engineering and Applied Sciences 3 (11), 2023-2029 (2016)

5. L. Cabral, Research in Economics 70 (4), 735-740 (2016)

6. A. Borboni, R. Faglia, Journal of Applied Mechanics, Transactions ASME 80 (2), 021003 (2013) DOI: 10.1115/1.4007721 10.1115/1.4033831 